\title{
Determinants of family employee work performance and compensation in family businesses
}

\author{
S.P. van der Merwe* \\ Potchefstroom Business School, North-West University, \\ Private Bag X6001, Potchefstroom 2531, Republic of South Africa \\ Stephan.vandermerwe@nwu.ac.za
}

Received November 2008

\begin{abstract}
This study highlighted the importance of establishing clear work roles and responsibilities in the family business, the measurement of family employee work performance and regular feedback on their performance and fair and market-based compensation of family employees in family businesses. An Oblimin oblique rotation was performed on the principal components of the exploratory factor analysis. In this study three factors describing the theoretical dimensions of family employee work performance, clear work roles and responsibilities and family employee compensation in family businesses were extracted. Although statistical significant differences were found between the perceptions of male and female as well as between senior and younger generation family employees regarding the constructs, these differences were not practically significant. This study, however, confirms the important role that an effective family employee work performance management and compensation strategy plays to ensure harmonious family relationships and at the end the sustainability of the family business. Practical recommendations are suggested to improve the effectiveness of family employee work performance and compensation in family businesses. Recommendations are also offered to utilise the questionnaire as a diagnostic tool.
\end{abstract}

*To whom all correspondence should be addressed.

\section{Introduction}

The important contribution of family businesses to economic growth and wealth creation in the world has been emphasised by numerous scholars (Basu, 2004:13; Morck \& Yeung, 2004:391; Astrachan \& Shanker, 2003:212; Ibrahim, Soufani \& Lam, 2001:245; Birley, Ng \& Godfrey, 1999:598). Van der Merwe (1998:3) points out that family businesses have been making a positive contribution towards the South African economy for the last 300 years. Ackerman (2001:325) concurs that approximately $80 \%$ of businesses in South Africa could be classified as family businesses and that they comprise $60 \%$ of the companies listed on the Johannesburg Stock Exchange.

Although the field of family business, according to Klein, Astrachan and Smyrnios (2005:321), has been regarded as a separate academic discipline since the 1990s (Bird, Welsh, Astrachan \& Pistrui, 2002), it only recently emerged as a topic within mainstream business research (Steier \& Ward, 2006; Chrisman, Chua \& Steier, 2003). Brockhaus (1996:3) points out that, also in South Africa, relatively little research has been carried out on family-run businesses. Although research on family businesses in South Africa gained some momentum during the paste decade (Van der Merwe, 2007; Van der Merwe \& Ellis, 2007; Venter \& Boshoff, 2006; Adendorff, Boshoff, Court \& Radloff, 2005; Venter, 2003a; Venter, 2003b; Venter, Boshoff \& Maas, 2003; Van der Merwe 1998; among others), more scientific-based research is urgently needed to gain more insight in the unique challenges facing the family business.

In a survey conducted by the Family Business Magazine (Autumn 1999) respondents rated family employee compensation second only to succession as a key concern as they looked back over the past ten years and ahead to the next ten years (Hoover \& Hoover, 2001:68). Aronoff and Ward (1993:59) highlighted the growing importance of family employee compensation as more second and third generation heirs enter the family business. Questions about remunerating family employees can, therefore, become increasingly complex and unmanageable as a family business grows and passes from generation to generation.

Brooks (2001:37), as well as Aronoff, Astrachan and Ward (2002:425), believe that a compensation program has no foundation unless job descriptions indicating the work roles and responsibilities have been prepared in sufficient detail to serve as a means of structuring wage classifications and of rating performance. Jaffe (1991:199) points out that family members should have real responsibilities for a clear area of the business and performance should be reviewed regularly.

Little evidence could be found of empirical-based research on family employee work performance and compensation in small and medium-sized businesses. There is ample justification, against the barren background of scientific value-added research, to pursue more earnest investigations into the role of family businesses globally, in general, and 
specifically in the South African economy. The objective of this study is to gain insight in the dynamics of family employee work performance and compensation in small and medium-sized family businesses.

For the purpose of this study, a family employee refers to a family member who is permanently employed by the family business. This includes family members of the senior generation (parents) and the younger generation (offspring).

\section{Objectives of the study}

The primary objective of this study was to empirically explore some of the determinants of family employee work performance and compensation in small and medium-sized family businesses. In order to address the primary objective, the following secondary objectives were formulated:

- To gain insight into the dynamics of family employee work performance and compensation in family businesses by means of a literature review.

- To identify the items that could measure family employee work performance and compensation in small and medium-sized family businesses.

- To validate the diagnostic questionnaire by means of statistical analysis.

- To examine the relationships (correlation) between the constructs, i.e. family employee work performance, clear work roles and responsibilities and family employee compensation.

- To examine the relationship between the constructs, i.e. family employee work performance, clear work roles and responsibilities and family employee compensation, and the demographic variables gender (male and female) and generation (senior and younger generation) of participating family members.

- To examine the relationship between the constructs, i.e. family employee work performance, clear work roles and responsibilities and family employee compensation, and the demographic variable business size (small and medium) of participating family businesses.

- To offer recommendations to improve the measuring questionnaire.

- To suggest practical recommendations to improve the effectiveness of family employee work performance and compensation in small and medium-sized family businesses.

\section{Defining small and medium-sized family businesses}

As noted by Bork (1993:24) and verified by Neubauer and Lank (1998:3), there is no consensus for the definition of family businesses in the research, consulting communities, among journalists and the general public. Various scholars reviewed existing definitions, and attempted to consolidate thoughts and conceptualised other definitions on family businesses (Chrisman, Chua and Sharma, 2005:556; Habbershon, Williams and MacMillan, 2003:451; Chua, Chrisman \& Sharma, 1999:19; Neubauer \& Lank, 1998:5; Goodman \& Dreux IV, 1997:1; Litz, 1995:71; Brockhaus, 1994:30; Bork, 1993:24; Lea, 1991:5; Handler, 1990:37).

For the purpose of this study, the definition of Ibrahim and Ellis (2004:5) has been adopted. They define a family business as follows: at least 51 percent of the business is owned by a single family; at least two family members are involved in the management or operational activities in the business; and the transfer of leadership to next generation family members is anticipated.

The South African National Small Business Act (1996) and National Small Business Amendment Bill (29/2004:2) classify micro, very small, small and medium-sized businesses as businesses that employ fewer than 200 fulltime equivalent of paid employees.

The focus of this study was thus small and medium-sized family businesses, as defined above.

\section{Operationalisation of constructs}

\section{Clear work roles and responsibilities in the family business}

Neubauer and Lank (1998:153) make the statement that a family member should not regard entrance to a family business as a right. Murak (2001:12) stressed that the ground rules for employment of family members should be established before they should be allowed to enter the business. Neubauer and Lank (1998:153) argue that the decision to permit family members into the business without the person adding sufficient value does not make business sense. Such actions threaten the sustainability of the family business.

Jaffe (1991:199) stated that when any family member enters a family business, a specific job position should be clearly delineated. Using job descriptions in recruiting and measuring the work performance of family employees suggest that positions will be awarded and compensated on merit and accomplishments, not family membership (Loeb, 2001:59). The job description should identify key duties, responsibilities and spans of authority in the family business (Brooks, 2001:37). It is by no means complete, because casual tasks and informal expectations are constantly being introduced and deleted by supervisors and peers alike. However, the job description should be sufficiently detailed to allow knowledgeable parties to value the core job elements is to establish a score that reflects the job's value to the business (Brooks, 2001:37).

The establishment of clear work roles and responsibilities is thus important for the effective employment of family members in family businesses. This construct will be referred to as clear work roles and responsibilities in this study. 


\section{Performance management of family employees}

No family business should feel obliged to hire incompetent relatives (Buchholz, Crane \& Nager, 2000:277). Voeller, Fairburn and Thompson (2002:73) recommended that performance expectations could be drawn up to help ensure that all family employees meet the same standards and receive the same support. This will remove any legitimate grievances on the part of their peers and the frustration that comes from being held to a higher standard than anyone else.

Loeb (2001:60) claims that when standards are established at the time of employment, and non-performance implications are clearly explained as set out in the supportive disciplinary policy, family employees are less likely not to conform to performance standards. By linking compensation to performance, family employees have incentives to work at an optimal level.

Jaffe (1991:199) recommended that either inside the family or in the business, performance should be assessed. Jonovic (1997:xxiii) supported the importance of performance measurement and added that in order to effectively manage a business as an investment, a formalised process of performance evaluation should be developed. Driscoll and Korman (2001:61) also emphasised the importance of performance measurement for family business success.

Family members can't improve if they don't know how well they are doing. The performance of family members should be objectively evaluated on a regular basis followed by honest feedback (Jonovic, 1997:xxiii). Furthermore, the reporting lines of the family members should be clearly defined and communicated to relevant parties in the family business. Performance standards that are applied uniformly strengthen employee morale, enhance productivity and help avoid strained family relationships (Jaffe, 1991:199).

Buchholz et al. (2000:276) state that every family business should establish how undesirable behaviour of family members should be managed. Family employee discipline is an emotional issue, but Sander and Bordone (2006) confirm that the sting can be taken out of disciplinary procedures by having clear rules and procedures in place. Hellriegel, Jackson and Slocum (2002:51) stated that members of a business need to respect the rules and agreements that govern it. If low work performance or unsatisfactory behaviour by a family employee can not be resolved within the family, the family business should seek professional help and strongly encourage the offending family member to address the issue (Buchholz et al., 2000:278).

If a family employee isn't performing to expectations, action should be taken (Loeb, 2001:59). The punishment should, however, be in light of the severity of the offence. These actions could include transferring the family employee to a more appropriate job or additional training may be needed. If the offence is severe, it could lead to the dismissal of the family employee (Buchholz et al., 2000:278). The dismissal of any low-performing employee, including family employees, may be necessary for the overall good of the family business and, ultimately for the family owners. Loeb
(2001:60) adds that a family business' failure to cull lowperforming employees (including family members) discourages higher performers and could hinder the overall productivity of the business.

Various authors stressed the importance of the measurement and feedback of family employee work performance (Driscoll \& Korman, 2001:61; Neubauer \& Lank, 1998:153; Jonovic, 1997:xxiii) and a formal disciplinary policy (Sander \& Bordone, 2006; Loeb, 2001:59; Buchholz et al., 2000:276) to ensure the long term success of family businesses. This construct will be referred to as family employee work performance in this study.

\section{Compensation of family employees}

Compensation is an issue in any business (Spector, 2001:7). In a family-owned business the emotions are amplified and the stakes are high. Because it is such a sensitive issue, most families do not do a very good job at coming up with a rational compensation system (Aronoff et al., 2002:137; Bork, Jaffe, Lane, Dashew \& Heisler, 1996:75). Business owning families often confuse the issues of fairness and equality, and, rather than pay fair market value for each individual's contribution on the job, pay everyone equally (Bork et al., 1996:75). A well-planned and carefully structured compensation system, however, one which demonstrates a distinct connection between pay and results, can effectively increase owner value and reduce conflict (Jonovic, 1997:xxiii). Koenig (2000:37) stated that one best practice that family businesses would do well to adopt is merit rewards.

All employees, including family members, should be paid competitive market value compensation for their jobs (Barrett, 2001:19). Benefits that a member of the family receives largely as a result of family membership should be so labelled. Family members, in addition to being paid money on which to live, need recognition and a yardstick of achievement (Barrett, 2001:19). Cash is only one form of recognition, and market value is only one form of achievement measurement. Compensation, to be truly effective, should include more than money alone. Extra money may be available through incentive schemes, bonus programs and the like (Barrett, 2001:19).

The most important issue regarding family compensation is that a compensation policy is adopted, recorded, communicated and followed (Rawls, 1999:57). Rawls (1999:57) stated that the only way to be really sure one has a compensation plan is for it to be in writing. Bork (1993:14); Maas, Van der Merwe and Venter (2005:39) and Syms (1992:142) all agree that a great deal of trouble can be avoided by having a written compensation policy.

Once a compensation strategy is established, the business owners should work to build trust in it. The philosophy should be communicated clearly to family members and other employees (Ward, 2004:78). This can be done in individual sessions, executive meetings, and family forum meetings. The message should be conveyed in a way that makes the business owner's priorities clear and stresses the 
relationship between employee pay and broader strategic goals (Aronoff \& Ward, 1993:59).

Thus, family employee compensation needn't be a thorny issue. The trick is to have a compensation strategy which is consistent, fair and open. Resentment and conflict tend to occur when these three attributes are missing (Buchholz et al., 2000:262).

The market value compensation system is designed to enhance the longevity of the family business, and reduce the conflicts, both intra-family and intra-business that often exist due to compensation factors (Aronoff \& Ward, 1993:59). The system enhances the separate aspects of the family and the business to create a healthier environment ultimately beneficial to the growth of the business and the family's wealth (Jaffe, 1991:199).

Family employee compensation, therefore, should be fair (Brockhaus, 2001:23; McClure, 2001:41), on merit (Koenig, 2000:37), market-based (Barrett, 2001:19; Lane, Dashew, Bork, Paul \& Jaffe, 2001:14), linked to actual work performance and value-adding (Brockhaus, 2001:23), linked to the amount of responsibility (Brockhaus, 2001:23), put in writing (Rawls, 1999:57) and communicated to all stakeholders (Ward, 2004:78; Buchholz et al., 2000:262). This construct will be referred to as family employee compensation in this study.

\section{Research methodology}

\section{Development of the questionnaire}

The literature review provided valuable insight into the identification of relevant issues regarding family employee work performance and compensation in family businesses. Based on the literature review four latent constructs related to family employee work performance and compensation were identified which could be used to measure the perceptions of family members regarding these issues. These are: clear work roles and responsibilities in the family business, performance measurement of family members, existence of disciplinary procedures in the family business and compensation policy for the family business. A questionnaire was designed to assess these constructs.

The questionnaire was developed in three phases: firstly, the items to measure each latent construct were formulated after a literature review; secondly, the questionnaire was tested in a single family business; thirdly, the questionnaire was piloted in nine family businesses with 71 family members who completed the pilot questionnaires. The questionnaire was then refined after each phase, followed by the drafting of an adapted version of the questionnaire.

The third version of the questionnaire (used in this study) assessed the four latent constructs using a 20-item scale. Items were rated on a 7-point Likert scale ranging from $1=$ strongly disagree to $7=$ strongly agree.

Demographic information, which included an indication of the gender and generation of respondents (senior or younger generation) and age classification, were collected.
Information on the structure of the participating family businesses included the size classification and turnover of the business, were also collected.

\section{The study population}

The target population of this study was small and mediumsized family businesses in South Africa. Numerous attempts were made to secure a database of family businesses in South Africa, but to no avail. Therefore, it was decided to use a convenience sample, by means of the snowball sampling technique, to identify the family businesses that participated in this study (Page \& Meyer, 2000:100). This data should be considered as generated from a small study population for which statistical inference and $p$-values are not relevant (Ellis \& Steyn, 2003:51).

To generate a preliminary list of family businesses, wellknown business people were contacted in various regions in South Africa. These business people then acted as informants and identified potential family businesses for inclusion in the sample. The identified potential family businesses then identified a further set of family businesses. These referrals were subsequently contacted telephonically to confirm that they fitted the definition of small and medium-sized family businesses used in this study (Ibrahim \& Ellis, 2004:5; National Small Business Amendment Bill, 2004:2; National Small Business Act, 1996) and to gauge their willingness to participate in the study. A list of 185 family businesses willing to participate in the study was compiled as a result of these efforts.

\section{Data collection}

The techniques to distribute and complete the questionnaires were as follows: distribution of questionnaires via post, email or facsimile, personal delivery of questionnaires, followed up by telephone calls, telephone interviews, or structured interviews (Neuman, 1997:251-263; Bless \& Higson-Smith, 1995:112; Du Plooy, 1995:109-124). Each questionnaire was sent with a covering letter that guaranteed the confidentiality of their responses, as well as a returnpaid envelope in order to make it as easy as possible for respondents to take part in the research.

A total of 654 usable questionnaires were returned from 119 family businesses. The objective of this study was to assess the perception of both the senior generation (parents) and younger generation (offspring) family employees on family employee work performance, work roles and responsibilities and family employee compensation family businesses. Therefore, only family businesses where family members of both the senior and younger generation are employed by the business were included in this study. For the purpose of this study, the 119 businesses were, therefore, narrowed down to 81 businesses with 298 participating family employees.

\section{Statistical analysis}

The data collected were statistically analysed, using Statistica (Statsoft, 2006) and SPSS (SPSS, 2005). Construct validity of the questionnaire was assessed by means of an exploratory factor analysis and by calculating Cronbach 
alpha coefficients. The relationship between the three constructs, i.e. family employee work performance, clear work roles and responsibilities and family employee compensation was examined by means of correlation analysis. Thereafter, the relationship between the demographic variables family employee gender and generation, business size; and the constructs was explored by means of paired tests.

To address the objectives of this study, the following propositions were formulated:

$\mathbf{P}^{1}$ : The measuring questionnaire has acceptable construct validity

$\mathbf{P}^{2}$ : The measuring questionnaire has acceptable reliability

$\mathbf{P}^{3}$ : There is a correlation (relationship) between the three constructs, i.e. family employee work performance, clear work roles and responsibilities and family employee compensation

$\mathbf{P}^{4}$ : There is a difference between the perception of male and female family employees with regard to the constructs, i.e. family employee work performance, clear work roles and responsibilities and family employee compensation

$\mathbf{P}^{5}: \quad$ There is a difference between the perception of the senior and younger generation family employees with regard to the constructs, i.e. family employee work performance, clear work roles and responsibilities and family employee compensation

$\mathbf{P}^{\mathbf{6}}$ : There is a difference between the perception of family members employed by small and mediumsized family businesses with regard to the constructs, i.e. family employee work performance, clear work roles and responsibilities and family employee compensation

\section{Findings and discussion}

\section{Demographic information}

Table 1 shows that the majority of the 298 participating respondents were under the age of 40 years $(47,65 \%)$, $11,07 \%$ between the ages of 40 and 49 , with $41,28 \%$ over the age of 50 years. Approximately two-thirds of the respondents were male $(64,09 \%)$. A total of $44,29 \%$ of the respondents were senior generation family employees (parents), with 43,96\% representing the younger generation family employees (offspring). The rest of the family employees $(11,75 \%)$ represented in-laws (married to younger generation family members) and other family employees such as uncles, aunts or cousins.

Sixty two $(76,54 \%)$ of the 81 family businesses who participated in this study can be categorised as small businesses in the South African context (less than 50 permanent employees). The rest $(23,46 \%)$ can be categorised as medium-sized businesses (between 51 and 200 employees).

Although family businesses from all provinces in South Africa took part in this study, owing to the convenience sampling technique, this sample can not be considered representative of all small and medium-sized family businesses in South Africa.

Table 1: Demographic information of the sample

\begin{tabular}{|c|c|c|}
\hline Factor & Frequency & Percentage (\%) \\
\hline \multicolumn{3}{|l|}{ Gender $(n=298)$} \\
\hline Male & 191 & 64,09 \\
\hline Female & 107 & 35,91 \\
\hline \multicolumn{3}{|l|}{ Generation $(n=298)$} \\
\hline $\begin{array}{l}\text { In-laws (younger } \\
\text { generation) }\end{array}$ & 30 & 10,07 \\
\hline $\begin{array}{l}\text { Senior generation } \\
\text { (parents) }\end{array}$ & 132 & 44,29 \\
\hline $\begin{array}{l}\text { Younger generation } \\
\text { (offspring) }\end{array}$ & 131 & 43,96 \\
\hline $\begin{array}{l}\text { Other (e.g. uncles, } \\
\text { aunts, cousins) }\end{array}$ & 5 & 1,68 \\
\hline \multicolumn{3}{|c|}{ Age category (years) $(n=298)$} \\
\hline Younger than 29 & 63 & 21,14 \\
\hline $30-39$ & 79 & 26,51 \\
\hline $40-49$ & 33 & 11,07 \\
\hline $50-59$ & 72 & 24,16 \\
\hline Older than 60 & 51 & 17,12 \\
\hline \multicolumn{3}{|c|}{ Business size (permanent employees) $(n=81)$} \\
\hline $1-50$ (small business) & 62 & 76,54 \\
\hline $\begin{array}{l}51-200 \text { (medium-sized } \\
\text { business) }\end{array}$ & 19 & 23,46 \\
\hline
\end{tabular}

\section{Construct validity of the questionnaire}

It is, according to Bless and Higson-Smith (1995:130), important that researchers evaluate the measures or instruments that they use. This can be done by evaluating, among others, the reliability and construct validity of measures (Page \& Meyer, 2000:84). The construct validity of a questionnaire refers to the extent that it measures the theoretical dimensions (Anastasi \& Urbina, 1997:126). If there is evidence of construct validity, the questionnaire then measures what it is supposed to measure. Exploratory factor analysis can be used as a technique to identify groups of variables, measuring the so-called latent variables or theoretical dimensions in a data set (Field, 2005:619). To improve the interpretation of the extracted factors, a technique called factor rotation is used to discriminate between factors. When there is good theoretical reason to believe that the extracted factors are correlated, an oblique rotation should be performed (Field, 2005:636).

To assess the discriminant validity of the 20 items measuring family employee work performance and compensation in family businesses, an exploratory factor analysis was conducted using the computer programme SPSS (SPSS, 2005). In this study, there was theoretical justification to believe that the factors measuring the constructs would correlate with each other and therefore an Oblimin oblique rotation was performed on the principal components of the exploratory factor analysis, as suggested by (Field, 2005:636). 
Table 2: Pattern matrix of Oblimin rotated-principal component factor analysis ${ }^{(1)}$

\begin{tabular}{|c|c|c|c|c|}
\hline Nr. ${ }^{(2)}$ & Item & $\begin{array}{l}\text { Factor } 1^{(3)} \\
\text { Work } \\
\text { performance }\end{array}$ & $\begin{array}{c}\text { Factor } 2 \\
\text { Roles and } \\
\text { responsibilities }\end{array}$ & $\begin{array}{c}\text { Factor } 3 \\
\text { Compensation }\end{array}$ \\
\hline Dic1 & $\begin{array}{l}\text { Clear ground rules exist for disciplinary action against family } \\
\text { members }\end{array}$ & 0,928 & $-0,136$ & $-0,045$ \\
\hline Dic2 & $\begin{array}{l}\text { A clear policy exists regarding actions to be taken should a } \\
\text { family member in the family business under perform }\end{array}$ & 0,921 & $-0,141$ & $-0,085$ \\
\hline Dic4 & $\begin{array}{l}\text { A clear policy exists regarding actions to be taken if a family } \\
\text { member in the family business habitually acts in an irresponsible } \\
\text { way }\end{array}$ & 0,894 & $-0,001$ & 0,026 \\
\hline Dic3 & $\begin{array}{l}\text { The family knows what to do if a family member has to be } \\
\text { disciplined }\end{array}$ & 0,767 & 0,071 & $-0,031$ \\
\hline RR4 & $\begin{array}{l}\text { Formal job descriptions for family members exist in the family } \\
\text { business. }\end{array}$ & 0,677 & 0,250 & 0,108 \\
\hline PM3 & $\begin{array}{l}\text { The work performance of family members in the family business } \\
\text { is regularly compared with previously determined objectives }\end{array}$ & 0,629 & 0,220 & $-0,064$ \\
\hline PM1 & $\begin{array}{l}\text { The work performance of family members in the family business } \\
\text { is evaluated regularly }\end{array}$ & 0,571 & 0,161 & $-0,142$ \\
\hline RR1 & $\begin{array}{l}\text { Family members in the family business have clear work roles and } \\
\text { responsibilities }\end{array}$ & $-0,004$ & 0,899 & 0,003 \\
\hline RR5 & $\begin{array}{l}\text { Every family member knows for which area of the family } \\
\text { business he or she is responsible }\end{array}$ & $-0,007$ & 0,859 & $-0,073$ \\
\hline RR2 & $\begin{array}{l}\text { Family members in the family business know what is expected of } \\
\text { them in the work situation }\end{array}$ & 0,060 & $\mathbf{0 , 8 2 7}$ & $-0,018$ \\
\hline RR3 & Family members in the family business know who to report to & 0,069 & 0,601 & $-0,122$ \\
\hline Com5 & $\begin{array}{l}\text { Family members are compensated according to their contribution } \\
\text { to the business and not according to age or gender }\end{array}$ & $-0,089$ & 0,057 & $-0,907$ \\
\hline Com6 & $\begin{array}{l}\text { There is a direct link between work performance and } \\
\text { compensation }\end{array}$ & 0,043 & $-0,051$ & $-0,904$ \\
\hline Com 2 & $\begin{array}{l}\text { There is a direct link between the amount of responsibility and } \\
\text { compensation in the family business }\end{array}$ & 0,014 & $-0,047$ & $-0,830$ \\
\hline Com 1 & $\begin{array}{l}\text { Family members in the family business are compensated at levels } \\
\text { consistent with the standards of the industry }\end{array}$ & $-0,016$ & 0,136 & $-0,784$ \\
\hline Com4 & $\begin{array}{l}\text { The compensation to individual family members is reasonable } \\
\text { compared to the salaries of other family members }\end{array}$ & 0,089 & 0,238 & $-0,568$ \\
\hline Com3 & $\begin{array}{l}\text { The family business has a clear bonus and profit-sharing policy } \\
\text { in place }\end{array}$ & 0,308 & $-0,036$ & $-0,547$ \\
\hline \multicolumn{2}{|c|}{ Rotation sums of squared loadings } & 7,361 & 5,843 & 7,148 \\
\hline
\end{tabular}

(1) Loadings greater than 0,40 were considered significant

(2) Indicating the number of the items measuring the four latent constructs, i.e. clear work roles and responsibilities (RR); performance measurement of family members (PM); existence of disciplinary procedures (Dic) and compensation policy for the family business (Com)

(3) The three extracted factors were labelled as follow:

Factor 1:Family employee work performance (work performance)

Factor 2:Clear work roles and responsibilities (roles and responsibilities)

Factor 3:Family employee compensation (compensation)

Kaiser's criterion was used to extract three factors, i.e. only factors with eigenvalues greater than one were retained (Field, 2005:735). The loadings of three items, the work performance of family members in the family business is regularly compared with their critical performance areas (PM2), the work performance of family members in the family business is evaluated regularly (PM1) and the family business has a transparent compensation policy (Com7), could not be logically explained and were deleted. The remaining 17 items demonstrated sufficient discriminant validity by loading to a sufficient extent. The pattern matrix of the 17 items is provided in Table 2. Factor loadings greater than 0,40 were considered significant.

Three factors with eigenvalues greater than one, explaining $70,35 \%$ of the variance before rotation, were extracted in the exploratory factor analysis. After rotation, these factors could be identified as the theoretical dimensions of family employee work performance, clear work roles and responsibilities and family employee compensation. When factors are correlated, sums of squares of loadings cannot be added to obtain a total variance explained for the rotated factors as in the case of uncorrelated factors (SPSS, 2005). The Kaiser-Meyer-Olkin measure of sampling adequacy of 0,95 indicates that patterns of correlations are compact and that factor analysis should yield reliable factors (Field, 2005:640).

Factor one, labelled family employee work performance, comprised seven items and accounted for 53,48\% of the variance. This factor incorporates two latent constructs, namely performance measurement of family members and existence of disciplinary procedures in the family business. The following items loaded on this factor: Dic1, Dic2, Dic4, Dic3, RR4, PM3 and PM1. Take note that the latent construct, existence of disciplinary procedures in the family 
business, was incorporated into the extracted factor labelled family employee work performance.

The second factor, labelled clear work roles and responsibilities, comprised four items and accounted for $9,66 \%$ of the variance. The factor incorporates the latent construct clear work roles and responsibilities in the family business. The items with a significant loading were: RR1, RR5, RR2 and RR3.

The third factor, labelled family employee compensation, comprised six items and accounted for 7,21\% of the variance. This factor captures the latent construct compensation policy for the family business. The items, Com5, Com6, Com2, Com1, Com4 and Com3, loaded on this factor.

The exploratory factor analysis, together with the interpretability of the factors, provides some evidence of construct validity, indicating that Proposition 1 can be accepted.

\section{Reliability of the questionnaire}

In order to assess the internal consistency between the items of the measuring questionnaire, Cronbach's alpha coefficients were calculated (Page \& Meyer, 2000:292). An questionnaire that produces different scores every time that it is used on the same person under the same conditions has low reliability (Field, 2005:666). The Cronbach alpha coefficient is based on the average correlation of variables within a test (SAS Institute, 2005:295). The greater the Cronbach alpha coefficient, the more reliable the scale. Nunnally and Bernstein (1994:265) suggest that for acceptable reliability the Cronbach alpha coefficient should be greater than 0,7 . The Cronbach alpha coefficients for the three constructs, i.e. family employee work performance, clear work roles and responsibilities and family employee compensation, are presented in Table 3.

The results in Table 3 suggest that the questionnaire used in this study to measure family employee work performance and compensation, has acceptable reliability with no one factor measured with a Cronbach Alpha value below the customary cut-off value of 0,70 suggested for internal consistency (Nunnally \& Bernstein 1994:265). Proposition 2 can thus be accepted.

Table 3: Reliability of the constructs measuring family employee work performance and compensation in family businesses

\begin{tabular}{l|c}
\hline Factor & Cronbach alpha \\
\hline Family employee work performance & 0,922 \\
\hline Clear work roles and responsibilities & 0,871 \\
\hline Family employee compensation & 0,905 \\
\hline
\end{tabular}

\section{Relationship between the constructs}

To investigate the relationship between the three constructs, namely family employee work performance, clear work roles and responsibilities and family employee compensation, the Pearson correlation coefficients $(r)$ were calculated and are presented in Table 4 (refer to Field, 2005:111). Factor scores for each participant were computed as the average of all items contributing to the relevant factor. This means that missing values for an individual response were automatically replaced by the average of the other responses contributing to the relevant factor for the specific individual. The scores of family members belonging to a specific family can be considered to be dependent on that family's situation. As independence of data is a critical assumption of correlation analysis, the average counts for each of the 81 families were taken as data points in the correlation analysis.

In order to determine whether the effect of the relationship between two constructs is important or meaningful, the size of the effect should be measured. Effect sizes are useful because they provide an objective measure of the importance of an effect (Field, 2005:32). A correlation coefficient of 0 means there is no visible relationship, and a value of 1 means that there is a perfect relationship. Cohen (1992) made the following widely accepted suggestions about what constitutes a large or small effect:

- $\quad r=0,10$ (small effect): in this case, the effect explains $1 \%$ of the variance

- $\quad r=0,30$ (medium effect): the effect accounts for $9 \%$ of the variance

- $\quad r=0,50$ (large effect): the effect accounts for $25 \%$ of the variance (refer to Field, 2005:32)

The results in Table 4 indicate that there is a practically significant (large effect) relationship between all three constructs ( $r=0,66 ; 0,75$ and 0,81 respectively). Proposition 3 can be accepted.

Field (2005:128) warns that care should be taken when interpreting correlation coefficient results because the direction of causality could not be determined. Furthermore, a third variable could also have an influenced on a specific bivariate correlation.

Table 4: Correlation between constructs

\begin{tabular}{l|c|c|c}
\hline Variable & $\begin{array}{c}\text { Family } \\
\text { employee } \\
\text { work } \\
\text { performance }\end{array}$ & $\begin{array}{c}\text { Clear work } \\
\text { roles and } \\
\text { responsibilities }\end{array}$ & $\begin{array}{c}\text { Family } \\
\text { employee } \\
\text { compensation }\end{array}$ \\
\hline $\begin{array}{l}\text { Family } \\
\text { employee work } \\
\text { performance }\end{array}$ & 1,00 & 0,66 & 0,81 \\
\hline $\begin{array}{l}\text { Clear work } \\
\text { roles and } \\
\text { responsibilities }\end{array}$ & 0,66 & 1,00 & 0,75 \\
\hline $\begin{array}{l}\text { Family } \\
\text { employee } \\
\text { compensation }\end{array}$ & 0,81 & 0,75 & 1,00 \\
\hline
\end{tabular}


In order to measure the amount of variability in one construct that is explained by the other, the coefficient of determination $\left(R^{2}\right)$ were determined. The results indicate that $66 \%\left(r=0,81 ; R^{2}=0,66\right)$ of the variance between the constructs family employee work performance and family employee compensation is shared. The balance, $34 \%$, can be ascribed to measurement errors in family employee work performance and compensation, together with the influence of other unknown factors. Furthermore, $44 \%\left(r=0,66 ; R^{2}=\right.$ $0,44)$ of the variance in family employee work performance and clear work roles and responsibilities in the family business is shared. A total of $56 \%\left(r=0,75 ; R^{2}=\right.$ $0,56)$ of the variance in family employee compensation and clear work roles and responsibilities is shared. With regard to the last two correlations, the balance of the variance (56\%; 44\% respectively) can be ascribed to measurement errors in the constructs and other influences.

\section{Comparing the mean differences between constructs for demographic variables}

Statistical significance tests have the tendency to yield small p-values (indication of significance) as the size of the data set increases. The effect size, however, is independent of sample size and is a measure of practical significance (Ellis \& Steyn 2003:51). In this study, the recommendations will, therefore, be based on the findings of the effect sizes (dvalues).

The differences in the means between the extracted factors, namely family employee work performance, clear work roles and responsibilities and family employee compensation (see Table 1), for the demographic variables gender (male and female), generation (senior and younger) of the participating family employees and the size of the business (small and medium) were examined by an independent $t$-test ( $\mathrm{p}$-values) and effect sizes (d-values). The analysis was performed on a family level, where the average scores for each of the 81 families were taken as data points.

A natural way to comment on practical significance is to use the standardised difference between the means of two populations, i.e. the difference between the two means divided by the estimate for standard deviation, $\mathrm{d}=\frac{\left|\overline{\mathrm{x}}_{1}-\overline{\mathrm{x}}_{2}\right|}{\mathrm{s}_{\max }}$, where $\left|\overline{\mathrm{x}}_{1}-\overline{\mathrm{x}}_{2}\right|$ is the difference between $\overline{\mathrm{x}}_{1}$ and $\overline{\mathrm{x}}_{2}$ without taking the sign into consideration and $\mathrm{s}_{\max }=$ maximum of $\mathrm{s}_{1}$ and $\mathrm{s}_{2}$, of the sample standard deviations.

Effect sizes (d) will be interpreted, according to Cohen's guidelines, as follows: small effect $(d=0,2)$, medium effect $(d=0,5)$ and large effect $(d=0,8)$. Results with medium effects can be regarded as visible effects and with $d \geq 0,8$ as practically significant, since it is the result of a difference having a large effect (Field, 2005:32; Ellis \& Steyn, 2003:51-53; Thompson, 2001:80-93).

Table 5 shows the relationships between the three constructs and the demographical variables gender, generation and business size respectively, with the mean $(\overline{\mathrm{x}})$, standard deviation (s), independent $t$-test ( $\mathrm{p}$-value) and effect sizes (d-value).

The results indicated a statistically significant difference $(\mathrm{p}$ $<0,05)$ in the mean values between the perceptions of male and females with regard to the three constructs, family employee work performance $(p=0,03)$, clear work roles and responsibilities $(p=0,03)$ and family employee compensation $(p=0,005)$.

Although male participants rated the three constructs, family employee work performance, clear work roles and responsibilities and family employee compensation more positive than their female counterparts, the differences were not practically significant and only a small effect $(\mathrm{d}=$ 0,$21 ; \mathrm{d}=0,25$ and $\mathrm{d}=0,28$ respectively) could be determined. The results indicate that, although the average scores for male family employees are higher than those for female family employees, it could not be regarded as a practically significant difference between the perceptions of male and female family employees regarding family employee work performance, clear work roles and responsibilities and family employee compensation. Based on Cohen's guidelines (Ellis \& Steyn, 2003:51-53), proposition 4 can thus not be accepted. 
Table 5: The results of the differences in means between the constructs for different demographic variables

\begin{tabular}{|c|c|c|c|c|c|c|c|c|c|c|c|c|c|}
\hline \multirow{2}{*}{\multicolumn{2}{|c|}{ Classification }} & \multicolumn{4}{|c|}{$\begin{array}{c}\text { Factor 1: Family employee work } \\
\text { performance }\end{array}$} & \multicolumn{4}{|c|}{$\begin{array}{c}\text { Factor 2: Clear work roles and } \\
\text { responsibilities }\end{array}$} & \multicolumn{4}{|c|}{$\begin{array}{c}\text { Factor 3: Family employee } \\
\text { compensation }\end{array}$} \\
\hline & & $\overline{\mathrm{x}}$ & $s$ & $\mathrm{p}$ & d & $\overline{\mathrm{x}}$ & $S$ & $\mathrm{p}$ & $\mathrm{d}$ & $\overline{\mathrm{x}}$ & $S$ & $\mathrm{p}$ & $\mathrm{d}$ \\
\hline \multirow{2}{*}{ نّ } & Male & 3,89 & 1,29 & \multirow{2}{*}{0,03} & \multirow{2}{*}{0,21} & 5,67 & 0,89 & \multirow{2}{*}{0,03} & \multirow{2}{*}{0,25} & 4,63 & 1,17 & \multirow{2}{*}{0,005} & \multirow{2}{*}{0,28} \\
\hline & Female & 3,57 & 1,54 & & & 5,34 & 1,31 & & & 4,25 & 1,40 & & \\
\hline \multirow{2}{*}{ 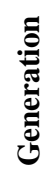 } & Senior & 4,10 & 1,35 & \multirow{2}{*}{0,06} & \multirow{2}{*}{0,19} & 5,84 & 0,90 & \multirow{2}{*}{$<0,001$} & \multirow{2}{*}{0,37} & 4,93 & 1,18 & \multirow{2}{*}{$<0,001$} & \multirow{2}{*}{0,36} \\
\hline & Younger & 3,81 & 1,53 & & & 5,38 & 1,28 & & & 4,40 & 1,47 & & \\
\hline \multirow{2}{*}{ 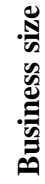 } & Small & 3,85 & 1,29 & \multirow{2}{*}{$<0,001$} & \multirow{2}{*}{0,40} & 5,50 & 0,98 & \multirow{2}{*}{$<0,001$} & \multirow{2}{*}{0,45} & 4,51 & 1,22 & \multirow{2}{*}{$<0,001$} & \multirow{2}{*}{0,43} \\
\hline & Medium & 4,36 & 1,27 & & & 5,94 & 0,74 & & & 5,03 & 1,08 & & \\
\hline
\end{tabular}

Although a statistically significant difference between the perceptions of senior and younger generation family employees concerning the constructs was indicated, only a medium effect on the factors clear work roles and responsibilities $(p<0,001 ; d=0,37)$ and family employee compensation $(p<0,001 ; d=0,36)$ respectively could be determined. The results indicate that, although the average scores for senior generation family employees are higher than those for younger generation family employees, it could not be regarded as a practically significant difference between the perceptions of senior and younger generation family employees regarding family employee work performance, clear work roles and responsibilities and family employee compensation. Proposition 5 can thus not be accepted. However, the results suggest that senior generation family employees are more positive about the clear work roles and responsibilities and family employee compensation than the younger generation family employees. The reason for this might be because senior generation family employees, in most instances also the current owner-manager, feel more in control of the policy and decision-making processes in the family business. Younger generation family employees, on the other hand, often feel excluded from those processes. The general trend that younger generation family employees often feel left out in work performance and compensation policy and decisionmaking which could result in negative perception about these issues is confirmed in literature (Aronoff \& Ward, 1993:47-50).

Family members employed by medium-sized family businesses rated the three constructs, family employee work performance $(\mathrm{p}<0,001)$, clear work roles and responsibilities $(\mathrm{p}<0,001)$, and family employee compensation ( $p<0,001)$, statistically significant more positive than family members employed by small family businesses, but the differences were not practically significant and only a medium effect $(d=0,40 ; d=0,45$ and $\mathrm{d}=0,43$ respectively) could be determined. The results indicate that, although the average scores for family members employed by medium-sized family businesses are higher than those for small family businesses, it could not be regarded as a practically significant difference between the perceptions of family members employed by medium or small family businesses regarding family employee work performance, clear work roles and responsibilities and family employee compensation. Proposition 6 can thus not be accepted.

\section{Conclusion}

Literature has shown that clear work roles and responsibilities form the basis for family employee work performance management and compensation in family businesses (Brooks, 2001:37; Jaffe, 1991:199). This study confirms this view.

This study reports some evidence of construct validity and reliability of a questionnaire to measure family employee work performance and compensation in small and mediumsized family businesses in South Africa. Three factors describing the theoretical dimensions of family employee work performance, clear work roles and responsibilities and family employee compensation, were extracted. It is recommended that more advanced statistical procedures for scale validation, such as structural equation modelling, be utilised in further development of the questionnaire.

The correlation matrix for the three extracted factors indicates practically significant correlations of 0,508 to 0,622 between the three factors (Ellis \& Steyn, 2003:53), confirming that an oblique rotation should have been used (Field, 2005:636).

Strong bivariate correlations of between 0,66 and 0,81 were calculated between the constructs. This means that, for 
instance, there was a strong positive correlation between the perceptions of family employees regarding family employee work performance and compensation. The direction of causality and the influence of other variables on a specific bivariate, could not be determined. Care should, therefore, be taken when interpreting the correlation coefficients. Further research on these constructs is recommended to gain more insight into the causality of the constructs.

No practically significant relationship could be found between the constructs, family employee work performance, clear work roles and responsibilities and family employee compensation; and the demographic variables gender (male and female) and generation (senior and younger family employees) of family employees respectively, as well as for family members employed by small or medium-sized family businesses.

Although the acceptance of propositions $\mathrm{P}^{4}, \mathrm{P}^{5}$ and $\mathrm{P}^{6}$ were based on Cohen's guidelines, it is important to take note of Thompson's argument (Thompson, 2001) not to use Cohen's guidelines in an overly rigid manner to interpreted the differences in means between variables. More empirical research is, therefore, needed to further examine these differences and to establish norms for future interpretation.

\section{Recommendations to improve the questionnaire}

In this study a questionnaire to assess the perceptions of family members regarding family employee work performance and compensation in family businesses was developed. A benefit that family businesses can derive from completing the questionnaire is that all family employees can obtain a personal advantage from the diagnosis especially the younger generation family members who often feel left out of the buzz of the business. Involvement in the diagnosis is important for their sense of acceptance within the family business and ownership in the planning, policy and decision-making processes in the business resulting in building mutual trust and respect between the senior and younger generation family employees.

By completing the questionnaire all family employees are given the opportunity to air their opinions about sensitive issues such as performance measurement and compensation that otherwise are often ignored or simply just not discussed at family forums, but are most important for the current and future success of the business. Completing the questionnaire could also ignite a new interest and consciousness of the family dynamics of the family business. An invigorating alignment of interests to the benefit of the whole family and the business could come into being. It is, however, recommended to keep the answers confidential. Confidentiality could ensure honesty and open-heartedness - critical to determine the underlying attitudes of individual family members on the various items investigated.

This study focused only on the assessment of the work performance and compensation of family employees. It is however important to set clear ground rules for the entry and exit of family members in the family business. These ground rules form the basis of an effective family employee work performance management and compensation strategy in the business. It is, therefore, recommended that items measuring the construct, family member entry into the family business and family member exit out of the business, be added in the next version of the questionnaire.

\section{Limitations and recommendations for future research}

The study attempted to make a contribution to the body of knowledge on family employee work performance and compensation in small and medium-sized family businesses and can be regarded as a small step towards moving away from the current dependence on anecdotal evidence and case studies. This study, however, only assessed some of the determinants of family employee work performance and compensation in a relative small sample of family businesses and can be regarded as an exploratory study. More comprehensive research is still needed to clarify all the underlying dimensions of family work performance and compensation in family businesses to enhance our understanding of these issues.

Although family businesses from all provinces in South Africa took part in this study, due to the convenience sampling technique, this cannot be considered to be representative of all small and medium-sized family businesses in South Africa. Care should therefore be exercised in the interpretation and utilisation of the results, and the findings of the study cannot be generalised. In other words, the typical family business could be underrepresented in the sample.

In this study the exploratory factor analysis of the measuring questionnaire assessing employee work performance and compensation provides some evidence of construct validity, but further research is needed before the questionnaire can be utilised to diagnose these issues in small and mediumsized family businesses. It is recommended that more advanced statistical procedures for scale validation, such as structural equation modelling, should be utilised in further development of the questionnaire. Supplementary research on the use of this measuring questionnaire is also necessary to refine its norms.

The research findings clearly indicate a statistically significance bivariate correlation between all three constructs. Care should, however, be taken when interpreting correlation coefficients because the direction of causality could not be determined. The influence of a third variable on a specific bivariate correlation should also be taken in account in the interpretation of these results (Field, 2005:128). More comprehensive research on the covariance is, therefore, recommended to gain more insight into the causes of the variations.

Based on the fact that published evidence of a quantitative nature (premised on empirical evidence of the determinants of family employee work performance and compensation in small and medium-sized family businesses) both nationally and internationally is altogether absent, the findings of this study presents challenges for further research. 


\section{Managerial implications}

The study's findings are useful from both a theoretical and managerial perspective. This study highlighted the importance of establishing clear work roles and responsibilities in the family business, the measurement of family employee work performance and regular feedback and fair and market-based compensation of family employees in small and medium-sized family businesses.

Family employee work performance and compensation are emotional issues that could create serious conflict in the family business. Family businesses should, therefore, establish policies regarding these issues long before the younger generation is ready to enter into the family business. Ward (2004:23) stressed that by establishing policies before they are needed those issues are given attention before they become personal and emotional and can therefore be addressed more comfortable and more rationally.

Family businesses are continually confronted with conflict as the result of unclear work roles and responsibilities and perceptions on the work performance and compensation of in particular, family employees. The following guidelines are suggested to effectively manage these issues:

- Establish a family employment, performance measurement and compensation policy for family members. Thus, set policies for family member employment, performance measurement and discipline, as well as all types of compensation, including bonuses, cost-of-living raises, perks and other benefits.

- If possible, make the policies clear before the family members enter the family business. Discuss and revisit these policies on a regular basis during family forum meetings.

- Set clear guidelines for work performance reviews and feedback.

- Incorporate some form of incentive or performancebased compensation that rewards family employees achieving goals.

It is furthermore recommended that family businesses establish a special group to resolve family employee work performance and compensation issues. This group could include the senior generation owner-managers (parents), other key family members, directors and non-family managers. The discussion of family employee work performance and compensation on a regular basis during family forum meetings can also play a pivotal role to ensure the success of the family business.

This study confirms the important role that an effective family employee work performance management and compensation strategy plays to ensure harmonious family relationships and at the end the sustainability of the family business. This makes this questionnaire a useful tool to identify the state of these factors in the family business.

\section{References}

Ackerman, R. 2001. Hearing grasshoppers jump: The story of Raymond Ackerman as told to Denise Prichard. Claremont: David Philip.

Adendorff, C., Boshoff, C., Court, P. \& Radloff, S. 2005. 'The impact of planning on good governance practices in South African Greek family businesses', Management Dynamics, 14(4):34-46.

Anastasi, A. \& Urbina, S. 1997. Psychological testing. $7^{\text {th }}$ Edition. New York, N.Y.: Prentice Hall.

Aronoff, C.E., Astrachan, J.H. \& Ward, J.L. 2002. Family businesses sourcebook. $3^{\text {rd }}$ Edition. Marietta, Ga.: Family Enterprise Publishers.

Aronoff, C.E. \& Ward, J.L. 1993. Family businesses compensation. Marietta, Ga.: Family Enterprise Publishers.

Astrachan, J.H. \& Shanker, M.C. 2003. Family businesses contribution to the U.S. economy: A closer look', Family Business Review, 16(3):211-219.

Barrett, J.E. 2001. 'Are you paying too much - or too little?' In The family business compensation handbook. Spector, B.(Ed.). Philadelphia, Pa.: Family Business Publishing.

Basu, A. 2004. 'Entrepreneurial aspirations among family business owners: an analysis of ethnic business owners in the UK', International Journal of Entrepreneurial Behaviour \& Research, 10(1/2):12-33.

Bird, B., Welsh, H., Astrachan, J.H. \& Pistrui, D. 2002. 'Family business research: The evolution of an academic field', Family Business Review, 15(4):337-350.

Birley, S., Ng, D. \& Godfrey, A. 1999. 'The family and the business', Long Range Planning, 32(6):598-608.

Bless, C. \& Higson-Smith, C. 1995. Fundamentals of social research methods: An African perspective. $2^{\text {nd }}$ Edition. Cape Town: Juta.

Bork, D. 1993. Family business, risky business: How to make it work. Aspen, Colo.: Bork Institute for Family Business.

Bork, D., Jaffe, D.T., Lane, S.H., Dashew, L. \& Heisler, Q.G. 1996. Working with family businesses: A guide for professionals. San Francisco, Calif.: Jossey-Bass.

Brockhaus, R.H., Sr. 1994. 'Entrepreneurship and family business research: Comparisons, critique, and lessons', Entrepreneurship Theory and Practice, 19(1):25-38.

Brockhaus, R.H., Sr. 1996. 'Family business in SouthernAfrica: An old new frontier'. Paper presented at the Ninth Annual Conference of the International Council for Small Business in Southern Africa, Nelspruit, May. 
Brockhaus, R.H., Sr. 2001. 'Salaries, gifts and dividends: do you know the difference'. In Spector, B. (Ed.). The family business compensation handbook. Philadelphia, Pa.: Family Business Publishing.

Brooks, G. 2001. 'Reviewing compensation policies and procedures'. In Spector, B. (Ed.). The family business compensation handbook. Philadelphia, Pa.: Family Business Publishing.

Buchholz, B.B., Crane, M. \& Nager, R.W. 2000. Arthur Anderson answers the 101 toughest questions about family businesses. Paramus, N.J.: Prentice Hall.

Chrisman, J.J., Chua, J.H. \& Sharma, P. 2005. 'Trends and directions in the development of a strategic management theory of the family firm', Entrepreneurship Theory and Practice, 29(5):555-575.

Chrisman, J.J., Chua, J.H. \& Steier, L.P. 2003. 'An introduction to theories of family business', Journal of Business Venturing, 18(4):441-448.

Chua, J.H., Chrisman, J.J. \& Sharma, P. 1999. 'Defining the family business by behaviour', Entrepreneurship Theory and Practice, 23(4):19-39.

Cohen, J. 1992. 'A power primer', Psychological Bulletin, 112(1):155-159.

Driscoll, M. \& Korman, M. 2001. 'Achieving competitive advantage through performance management'. In Spector, B. (Ed.). The family business compensation handbook. Philadelphia, Pa.: Family Business Publishing.

Du Plooy, G.M. 1995. Introduction to communication: Communication research. Kenwyn: Rustica.

Ellis, S.M. \& Steyn, H.S. 2003. 'Practical significance (effect sizes) versus or in combination with statistical significance (p-values)', Management Dynamics, 12(4):5153.

Field, A. 2005. Discovering statistics using SPSS. London: Sage.

Goodman, J.M. \& Dreux, D.R. IV 1997. Business succession planning and beyond: A multidisciplinary approach to representing the family-owned business. Chicago, Ill.: ABA Publishing.

Habbershon, T.G., Williams, M. \& MacMillan, I.C. 2003. 'A unified systems perspective of family firm performance', Journal of Business Venturing, 18:451-465.

Handler, W.C. 1990. 'Succession in family firms: a mutual role adjustment between entrepreneur and next-generation family members', Entrepreneurship Theory and Practice, 15(1):37-51.

Hellriegel, D., Jackson, S.E. \& Slocum, J.W. 2002. Management: a competency-based approach. $9^{\text {th }}$ Edition. Cincinnati, Oh.: South-Western.
Hoover, C.L. \& Hoover, E.A. 2001. 'Reconciling pay differences between first and second generation'. In Spector, B. (Ed.). The family business compensation handbook. Philadelphia, Pa.: Family Business Publishing.

Ibrahim, A.B. \& Ellis, W.H. 2004. Family business management: Concepts and practice. $2^{\text {nd }}$ Edition. Dubuque, Ia.: Kendall/Hunt.

Ibrahim, A.B., Soufani, K \& Lam, J. 2001. 'A study of succession in a family firm', Family Business Review, 14(3):245-258.

Jaffe, D.T. 1991. Working with the ones you love: Strategies for a successful family business. Berkeley, Calif.: Conari Press.

Jonovic, D.J. 1997. The ultimate legacy: how owners of family and closely held businesses can achieve real purpose. Cleveland, Oh.: Jamieson.

Koenig, N.N. 2000. You can't fire me I'm your father: What every family business needs to know for success. Washington, DC: Kiplinger Books.

Klein, S.B., Astrachan, J.H. \& Smyrnios, K.X. 2005. 'The F-PEC scale of family influence: Construction, validation, and further implication for theory', Entrepreneurship Theory and Practice, 29(3):321-339.

Lane, S.H., Dashew, L., Bork, D., Paul, J. \& Jaffe, D.T. 2001. 'Compensation in family businesses: How to make it work'. In Spector, B. (Ed.). The family business compensation handbook. Philadelphia, Pa.: Family Business Publishing.

Lea, J.W. 1991. Keeping it in the family: Successful succession of the family business. New York, N.Y.: Wiley.

Litz, R.A. 1995. 'The family business: toward definitional clarity', Family Business Review, 8(2):71-81.

Loeb, M.E. 2001. 'Employee evaluations and promotions in the family firm'. In Spector, B. (Ed.). The family business compensation handbook. Philadelphia, Pa.: Family Business Publishing.

Maas, G.J.P., Van der Merwe, S.P. \& Venter, E. 2005. Family businesses in South Africa: A practical governance guide. Stellenberg: GEB Consultants.

McClure, S.L. 2001. 'Transitioning to equitable base pay for family employees'. In Spector, B. (Ed.). The family business compensation handbook. Philadelphia, Pa.: Family Business Publishing.

Morck, R. \& Yeung, B. 2004. 'Family control and the rent seeking society', Entrepreneurship Theory and Practice, 28(4):391-409.

Murak, G. 2001. 'The seven-alarm fire of family business compensation. In Spector, B. (Ed.). The family business 
compensation handbook. Philadelphia, Pa.: Family Business Publishing.

National Small Business Act see South Africa.

National Small Business Amendment Bill see South Africa.

Neubauer, F. \& Lank, A.G. 1998. The family business: Its governance for sustainability. Hampshire: MacMillan.

Neuman, W.L. 1997. Social research methods: Qualitative and quantitative approaches. $3^{\text {rd }}$ Edition. Needham Heights: Allyn \& Bacon.

Nunnally, J. \& Bernstein, I.H. 1994. Psychometric theory. $3^{\text {rd }}$ Edition. New York, N.Y.: McGraw-Hill.

Page, C. \& Meyer, D. 2000. Applied research design for business and management. Roseville: McGraw-Hill.

Rawls, L.H. 1999. Seeking succession: How to continue the family business legacy. Maitland, Fla.: Horizon Business Press.

Sander, F.E.A. \& Bordone, R.C. 2006. All in the family: Mmanaging business disputes with relatives. Harvard Business School Publishing Corporation.

SAS Institute Inc., 2005. SAS Institute Inc., SAS OnlineDoc ${ }^{\circledR}$, Version 9.1, Cary, N.C.: SAS Institute.

South Africa. 1996. 'National Small Business Act 102 of 1996', Government Gazette, 377(17612).

South Africa. 2004. 'National Small Business Amendment Bill 26926 of 2004', Government Gazette, B23-2004.

Spector, B. 2001. 'Rational approaches to an emotional topic'. In Spector, B. (Ed.). The family business compensation handbook. Philadelphia, Pa.: Family Business Publishing.

SPSS Inc. 2005. SPSS ${ }^{\circledR} 14.0$ for Windows, Release 14.0.0, Copyright $₫$ by SPSS Inc. Chicago, Ill.: SPSS.

Statsoft, Inc. 2006. 'Statistica (Data Analysis Software System)'. Vers. 7.1. [Online] URL: www.statsoft.com

Steier, L.P. \& Ward, J.L. 2006. 'If theories of family enterprise really do matter, so does change in management education', Entrepreneurship Theory and Practice, 30(6):887-895.

Syms, M. 1992. Mind your own business: And keep it in the family. New York, N.Y.: MasterMedia.

Thompson, B. 2001. 'Significance, effect sizes, stepwise methods, and other issues: Strong arguments move the field', Journal of Experimental Education, 70:80-93.
Van der Merwe, S.P. 1998. 'Formal planning in family businesses in the Vaal Triangle', Ph.D. thesis, North-West University, Potchefstroom, South Africa.

Van der Merwe, S.P. 2007. 'Evaluation of the factors that ensure long-term sustainability of family farms', South African Journal of Agricultural Extension, 36:1-27. Dec.

Van der Merwe, S.P. \& Ellis, S.M. 2007. 'An exploratory study of some of the determinants of harmonious family relationships in small and medium-sized family businesses', Management Dynamics, 16(4):24-35.

Venter, E. 2003a. 'The succession process in small and medium-sized family businesses in South Africa', Ph.D. thesis, University of Port Elizabeth, Port Elizabeth, South Africa.

Venter, W.P. 2003b. 'The role of familiness in the performance of family business groups', M. Phil dissertation, Rand Afrikaans University, Johannesburg, South Africa.

Venter, E. \& Boshoff, C. 2006. 'The influence of familyrelated factors on the succession process in small and medium-sized family businesses', South African Journal of Management and Economic Sciences, 9(1):17-32.

Venter, E., Boshoff, C. \& Maas, G. 2003. 'The influence of relational factors on successful succession in family business: A comparative study of owner-managers and successors', South African Journal of Business Management, 34(4):1-13.

Voeller, M., Fairburn, L. \& Thompson, W. 2002. Exit right: A guided tour of succession planning for families-inbusiness-together. $2^{\text {nd }}$ Edition. Toronto: Summit Run.

Ward, J.L. 2004. Perpetuating the family business. New York, N.Y.: Palgrave MacMillan. 